\title{
Educational potential of the region: structural components and methodological approaches to assessment
}

\author{
Galina Siraya ${ }^{1}$, Irina Oleynikova ${ }^{1,1^{*}}$, and Tatyana Chernova $^{2}$ \\ ${ }^{1}$ Taganrog Institute of Economics and Management, 347900, Petrovskaya str., 45, Taganrog, Russia \\ ${ }^{2}$ Polytechnic Institute the branch of FSBIE DSTU in Taganrog, 347900, Petrovskaya str., 109-a, \\ Taganrog, Russia
}

\begin{abstract}
The essence and the key components of educational potential in a chosen territory are investigated. Theoretical basis and methodological approaches are to be used simultaneously to further assess educational potential in the territory; that gave us an opportunity to perform structural systematization of institutional, reproductive, and resource indicators which reflect educational potential's components. This approach gives an opportunity to carry on comparative estimation of educational potential in a chosen area within the certain time frameworks and taking into account maximum number of parameters that show territorial differences and dynamics of the educational potential's components. Impact of population density factors along with level and structure of development of a chosen territory on key institutional and reproductive indicators of educational potential in Russian macro-regions was evaluated. We present an argument for analysis of the dynamics of change of sectoral structure of regional economy under the influence of technological transformation is the basis for prediction of the key regional competencies as the basis for formation of qualitatively novel educational potential of a region that will correspond to modern technological paradigm.
\end{abstract}

\section{Introduction}

The concept of "educational potential of a territory" in modern economic literature is quite widely used and is one of the key issues in the study of regional economics. Namely, the solution of the task of forming and developing the national innovation system and the corresponding regional innovation subsystems in order to ensure the sustainable social and economic development of regions and the whole country depends on the state of the educational potential of the territories. Only its appropriate level and effective implementation can ensure the effectiveness of regional innovation processes, and as a result, economic growth and increased national competitiveness of the country.

Historically the human capital became the first concept in a number of concepts related to educational potential. Therefore research on education potential mainly within the

\footnotetext{
${ }^{1}$ Corresponding author: i.oleynikova@tmei.ru
} 
framework of the theory of human capital had been carried out and education as its most important component was considered. The modern concept of human capital in the late 50s - early 60 s of the $20^{\text {th }}$ century by Theodor William Schultz and Gary Becker as a part of Chicago neoclassical school was enunciated. Schultz and Becker substantiated the decisive role of a man, his abilities, and educational potential for the development of economics and society [1-2].

Academician S.G. Strumilin, who published the work "Economic Significance of Public Education" in 1924, is considered the founder of the theory of educational potential in our country, and in 1962 Academician Strumilin introduced an indicator of labor quality that determines the level of labor productivity and directly depends on the employee's skills. In the end of the $20^{\text {th }}$ century his successors, scientists of the Institute of World Economy and International Relations of the Russian Academy of Sciences R. Kapelyushnikov, V. Martsinkevich, V. Goylo, E. Gromov, V. Kudrov, N. Inozemtsev proceeded research in this area [3-5].

Most scientific works in this domain are fundamental and applied studies of economics of education which normally within the frameworks of the theory of human capital have been implemented, and considered education as the main component of human capital. To develop scientific construction of the concept "educational potential of the territory" is one of unresolved tasks which provide opportunity to consider it from the viewpoint of spatial approach, more specifically as a kind of economic resources and a constituent of the economic potential of a particular region.

\section{Materials and Methods}

Within the frameworks of research of regional innovation subsystems' development, the economic potential as a set of resources of a region required for its development is interpreted, and all the resources should be used to produce competitive products and overall satisfy needs of current and future generations, taking into account national and business interests [5]. The main components of the region's economic potential are natural resources, investment, innovation, production, finance, infrastructure potential, as well as intellectual capital and human capital they include educational potential. Education potential of a territory is an integral part and is created on the basis of regional innovative subsystems, and its completeness and efficiency of use create the basis for the progressive social and economic development of regions. In that context the structural components of the educational potential of a territory are established, methodological approaches to assessment are summarized, a set of indicators to determine the level of development of the territory's resource, institutional, and reproductive components is proposed, an analysis of the territorial features of the development of the educational potential of Russia is carried out. In the course of the study we used methods of spatial economics, the theory of regional reproduction, the theory of human capital, the theory of technological paradigms, system analysis, and also applied methods of economic statistical analysis.

\section{Results}

The educational potential of a territory is an integrated economic category including first of all institutional and reproductive components. The institutional component is a set of institutions for education and science that provide conditions for education within the framework of established standards of behavior. In general, the education and science system can be divided into general education and vocational education institutions (institutions of secondary vocational education, institutions of higher professional 
education, and institutions of additional education, postgraduate school, and doctoral studies).

Since we consider the educational potential of a territory within the framework of the regional economics we will allocate vocational education institutions as its core, since they are the source of highly qualified professional personnel capable to create and promote innovations. A special place in the structure of the educational potential of a region is given to the subsystem of secondary vocational education which in its essence should be regionally oriented when composing competencies of graduates. The educational potential of a particular region as the most important factor in the development of the territory depends on the presence and condition of high-tech enterprises in the region, and the regional production demands in highly qualified professional personnel in its turn should determine the directions of training in educational institutions in the region and, first of all, in secondary vocational education. It is the system of secondary vocational education that should provide training of specialists for new attractive positions, taking into account the intensive automation of production, the introduction of nanotechnology and the development of information and communication technologies.

Reproduction in the regional economy means the transformation of resources into material and intangible benefits in order to ensure the living environment of a certain territorially integral subject of the economy and society. The reproductive function of educational potential of a territory is to provide the region's economy with highly qualified professional personnel within the framework of the existing system of industry-specific education taking into account that the real sector of the economy indeed needs the competence of graduates. Considering the educational potential as a mean for development of regional innovation subsystems it should be noted that the maximum effectiveness of its reproduction is characterized by the achievement of the required level of these competencies and the sufficient qualification of graduates for innovative activities.

The educational potential of a territory includes a resource component acting a certain "platform" for its formation. The main resources include financial, material and technical, information, human and other resources. Since we have already allocated the institutional component of educational capacity that besides educational institutions with appropriate material support and technical equipment also includes the pedagogical personnel, hence to resource component will belong financial and electronic and information resources. Financial resources are primarily expenditures from regional budgets on education and investment in education, and electronic and information resources are the use of PCs and the Internet for educational purposes, as well as remote educational technologies for the implementation of educational programs.

A functional component that is the environment which created by geographically localized national innovative subsystems into the educational potential of a territory as special paradigm is included. From the one hand educational potential is innovative subsystems integral part, however from the other one it is developing in the environment of such subsystems' development.

Thus the educational potential of a territory is a set of available and possible for the implementation of the region's economy resources that are necessary for the development of regional innovative subsystems by providing the regional economy with highly qualified personnel. Institutionally educational potential of a territory by the number and composition of professional educational institutions is determined, and functionally by internal and external factors of the information and technology environment that by the relevant regional innovative subsystems is created. It is the functional component that determines quality and composition of the resource component, in the form of financing and informational support and technology equipment of professional educational institutions, and it determines the reproductive component too by providing the region's economy with 
specialists in the necessary amount and of the required level of training. The educational potential of a territory assembled in this way ensures the creation of a favorable environment for innovative activity and for the development of regional innovative subsystems. The structure of the educational potential of a territory as a factor for development of regional innovative subsystems is presented in Fig. 1 [6-7].

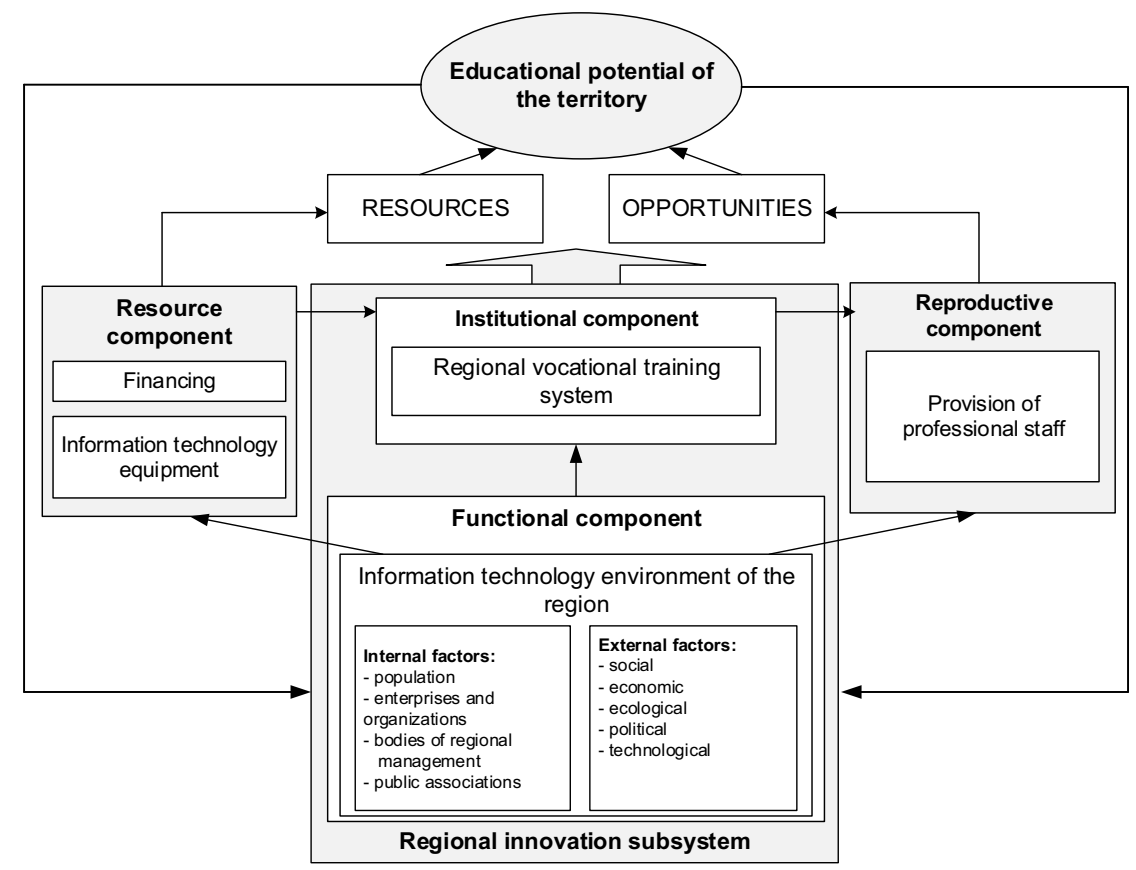

Fig. 1. The structure of the educational potential of a territory

In the structure of regional innovative subsystems, the educational potential of a territory is the main resource for the formation of key regional competencies that ensure the creation of the region's social and economic competitive advantages, its investment attractiveness and the effective development of regional innovative subsystems as the basis for sustainable social and economic development. Organization, successful development, and optimum utilization of educational potential of territories nowadays are one of the keys to building national innovation system in Russia.

Assessment of the educational potential of regions on the selection of a set of indicators that consistently and comprehensive characterize its structural elements is based. Validation the set of indicators on the following principles should be based on [8]

1) providing the highest possible accuracy of statistical information by using data of federal or regional government statistic agencies;

2) optimization of number of indicators by picking out the most sufficient ones from the point of view of estimation of the educational potential of a territory;

3 ) projection of specific character of the educational potential of a territory under consider and dynamics of its separate components.

Further we specify the set of indicators for every component of the educational potential of a territory, the indicators that comprehensively reveals its peculiarities including regional differences..

Institutional group by data of government statistics on composition of the system of professional education is determined and includes following social and economic indicators [9]: 
- number of educational institutions, including branches, that carry on educational activity according to programs of secondary vocational education (SVE) and higher education (HE);

- number of teachers and masters of vocational training (SVE) and number of highereducation teaching personnel of institutions (HE). We combined these indicators into two groups of synthetic indicators: institutional and personnel composition of the system of professional education.

We indicate two synthetic indicators for resource group they are financing of education, and electronic and informational technologies in education; we did so according to earlier determined composition of this component. According to statistic data from the digest "Regions of Russia" expenditures from consolidated budgets of regions of Russian Federation on education and level of investment in education belong to indicators of financing. Data to assess the level of development of information technologies for education purposes according to results of monitoring of information society development in Russian Federation is set [10]:

- number of PCs used for education purpose, included into local networks in institution of SVE and institutions of HE;

- percentage of educational institutions of HE with the speed of the Internet connection 2Mbps and higher;

- number of PCs used for educational purposes connected to the Internet in the SVE institutions and HE institutions;

- percentage of SVE institutions and HE institutions that have a web-site in the Internet;

- percentage of SVE institutions and HE institutions that implement educational programs using distant learning technology to deliver on main educational programs.

Reproductive group of indicators supply a region's subject of economy with professional personnel. Basing on statistical data of the digest "Regions of Russia" in the section "Education" [8] we assign two main synthetic indicators:

- coverage of population with vocational education; it is determined by number of students that study on the training plans of skilled workers and office workers, mid-level specialists and those who choose bachelor's, specialist's, master's degree programs;

- production of specialists by education institutions; it is determined by indicators of entering an education institutions and graduating from them of skilled workers and office workers, mid-level specialists and those who choose bachelor's, specialist's, master's degree programs.

As we consider the educational potential of a territory as an integral part of national innovative subsystems, hence to assess processes of its reproduction it is necessary to take into account rate of employment level of those who possess vocational education this is by employment of population aged 15-72 years old according to level of education is considered, and also one need to take into account the level of wages of employees.

The structure of indicators for assessing the educational potential of a territory in Fig.2 is given. Thus the condition of the education potential of a territory by three groups of indicators is characterized: institutional, resource, and reproductive, each of them includes particular indicators that show territorial differences taking into account factors of informational and technological environments within the frameworks of functioning regional innovative subsystems. All the indicators in their turn into groups of synthetic indicators are aggregated that provide their structural systematization. 


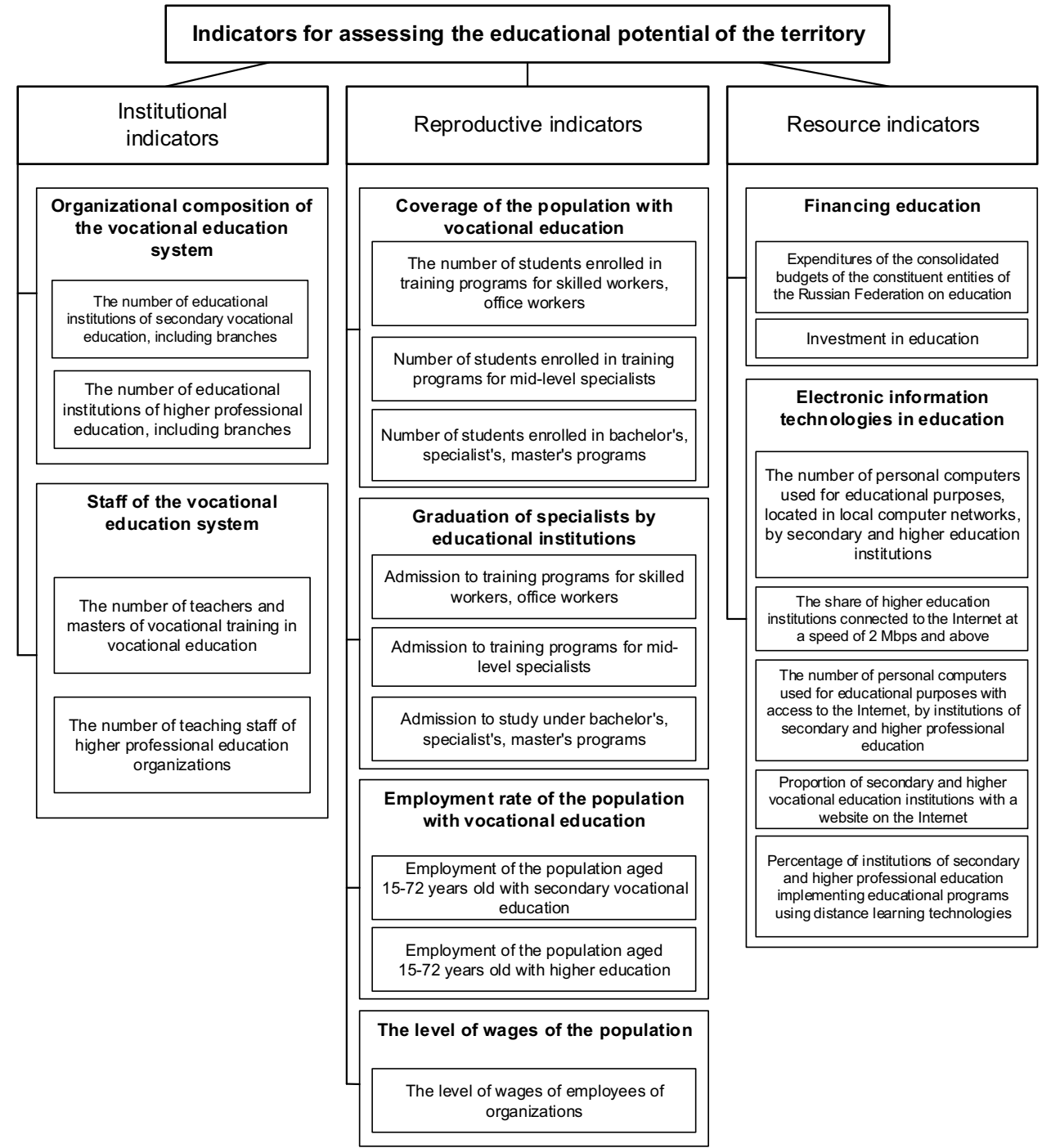

Fig. 2. The structure of indicators for assessing the educational potential of a territory

Dynamics of indicators that characterize structural components of the educational potential of a territory is influenced by the regional factors (such as density of population, and level of a region development). The development of the educational potential of a territory depends on its development resulting from population density, average annual number of employed persons, gross regional product, number of businesses and organizations. Further we analyze correlation among those indicators on the example of macroregions (Federal Districts of the Russian Federation). The key components of the educational potential (institutional and reproductive) are under influence of this factor [9]. Further we will determine correlation coefficient between the density of the system of professional education and population density (table 1), between normalized production of specialists by institutions of professional education and separate indicators of social and economic development of regions (table 2).

Table 1. Calculation of the dependence of the state of the vocational education system on the population density of the territory 


\begin{tabular}{|l|c|c|c|c|c|}
\hline \multicolumn{1}{|c|}{$\begin{array}{l}\text { Federal } \\
\text { District }\end{array}$} & $\begin{array}{c}\text { Area, 1000 } \\
\text { square km }\end{array}$ & $\begin{array}{c}\text { Population, } \\
\text { thousand } \\
\text { people }\end{array}$ & $\begin{array}{c}\text { Number of } \\
\text { SVE and HE } \\
\text { institutions }\end{array}$ & $\begin{array}{c}\text { Density of the } \\
\text { system of } \\
\text { professional } \\
\text { education, } \\
\text { number on } \\
\mathbf{1 0 0 0} \text { square } \\
\mathbf{k m}\end{array}$ & $\begin{array}{c}\text { Density of } \\
\text { population, } \\
\text { on 1 square } \\
\text { km }\end{array}$ \\
\hline Central & 650,2 & 39378,1 & 1204 & 1,85 & 60,56 \\
\hline Northwestern & 1687,0 & 13972,1 & 483 & 0,29 & 8,28 \\
\hline Southern & 447,8 & 16454,5 & 542 & 1,21 & 36,75 \\
\hline $\begin{array}{l}\text { Northern } \\
\text { Caucasus }\end{array}$ & 170,4 & 9866,8 & 312 & 1,83 & 57,9 \\
\hline Volga & 1037,0 & 29397,2 & 1112 & 1,07 & 28,35 \\
\hline Urals & 1818,5 & 12350,1 & 419 & 0,23 & 6,79 \\
\hline Siberian & 4361,7 & 17173,3 & 665 & 0,15 & 3,94 \\
\hline Far Eastern & 6952,6 & 8188,6 & 367 & 0,05 & 1,18 \\
\hline $\begin{array}{l}\text { Correlation } \\
\text { coefficient }\end{array}$ & & & & & 0,996 \\
\hline
\end{tabular}

Results of implemented calculations show that the number of professional educational institutions directly depends on population density, and dynamics of graduation of specialists from SVE institutions and HE institutions strongly depends on number of business and organizations that function and operate on a chosen territory, averagely depends on number of employed, and almost does not depend on Gross Regional Product.

Table 2. Calculation of the dependence of reproduction of the vocational education system from social and economic indicators

\begin{tabular}{|c|c|c|c|c|}
\hline Federal District & $\begin{array}{c}\text { Normalized } \\
\text { graduation of } \\
\text { specialists from } \\
\text { SVE institutions } \\
\text { and HE } \\
\text { institutions, } \\
\text { number of } \\
\text { persons on } 1 \\
\text { thousand people }\end{array}$ & $\begin{array}{c}\text { Normalized } \\
\text { annual average } \\
\text { of employed, } \\
\text { persons on } 1 \\
\text { thousand people }\end{array}$ & $\begin{array}{l}\text { Normalized Gross } \\
\text { Regional, million } \\
\text { Roubles on } 1 \\
\text { thousand people }\end{array}$ & $\begin{array}{c}\text { Normalized } \\
\text { number of } \\
\text { business and } \\
\text { organizations, } \\
\text { number on } 1 \\
\text { thousand } \\
\text { square km }\end{array}$ \\
\hline Central & 10,9 & 538,3 & 664,4 & 2,34 \\
\hline Northwestern & 9,6 & 506,8 & 586,6 & 0,32 \\
\hline Southern & 9,5 & 452,8 & 325,9 & 0,75 \\
\hline Northern Caucasus & 8,7 & 396,6 & 189,0 & 0,70 \\
\hline Volga & 10,4 & 465,5 & 375,1 & 0,70 \\
\hline Urals & 9,5 & 514,4 & 864,6 & 0,18 \\
\hline Siberian & 9,6 & 457,3 & 451,7 & 0,10 \\
\hline Far Eastern & 8,6 & 492,2 & 473,6 & 0,03 \\
\hline Correlation coefficient & & 0,527 & 0,352 & 0,708 \\
\hline
\end{tabular}

At present therefore the development of the educational potential of territories is rather subject to the demographic factor than the state of their economy.

The specialization of vocational training should depend on the industry characteristics of a region's economy determined by the industry structure of gross value added according to type of economic activity. We analyzed the ratio of the distribution of gross value added according to types of economic activity and the share of graduated specialists from higher and secondary vocational education institutions in the corresponding areas of training based on the materials of the Rostov region.

Structure of specialists' graduation of enlarged group of qualifications from HE institutions and SVE institutions we calculate basing on statistical reports of ministry of Science and Higher Education of the Russian Federation and Ministry of education of the 
Russian Federation $[11,12]$. Course of study we correlate to economic activity, this gives an opportunity to find out percentage of graduates in peculiar economic sectors. Results in table 3 are given.

Table 3. Relation of gross added value and graduation of specialists from HE institutions and SVE institutions in 2019 in the Rostov region

\begin{tabular}{|l|c|c|c|}
\hline \multicolumn{1}{|c|}{ Economic activity } & $\begin{array}{c}\text { Structure of gross } \\
\text { added value, } \%\end{array}$ & $\begin{array}{c}\text { SVE } \\
\text { graduates, } \\
\text { \% }\end{array}$ & $\begin{array}{c}\text { HE } \\
\text { graduates, } \\
\%\end{array}$ \\
\hline $\begin{array}{l}\text { Agriculture, forestry, hunting, fisheries and } \\
\text { aquaculture }\end{array}$ & 11,1 & 5,0 & 2,7 \\
\hline Mining & 1,2 & 1,5 & 2,5 \\
\hline Manufacturing & 20,6 & 22,1 & 13,3 \\
\hline $\begin{array}{l}\text { Electric power and natural gas supply, air } \\
\text { conditioning }\end{array}$ & 4,4 & 1,8 & 4,8 \\
\hline $\begin{array}{l}\text { Water supply, wastewater disposal, and waste } \\
\text { utilization }\end{array}$ & 0,9 & 1,4 & 2,0 \\
\hline Construction & 7,7 & 8,9 & 8,9 \\
\hline $\begin{array}{l}\text { Trade, repair and maintenance of automobiles and } \\
\text { motorcycles }\end{array}$ & 17,9 & 5,0 & 5,0 \\
\hline Transportation and storage & & & \\
\hline Hotels, catering & 6,8 & 10,9 & 7,3 \\
\hline Information and communication & 1,3 & 2,0 & 0,6 \\
\hline Finances and insurance & 2,1 & 7,2 & 9,2 \\
\hline Real estate & 0,2 & 3,0 & 4,4 \\
\hline Qualified personnel, science, engineering & 7,5 & 1,9 & 3,6 \\
\hline Management and corresponding activity & 2,7 & 0,0 & 7,3 \\
\hline Government, military security, social security & 1,7 & 4,9 & 9,2 \\
\hline Education & 4,8 & 3,0 & 4,4 \\
\hline Healthcare and social services & 3,3 & 3,4 & 4,8 \\
\hline Culture, sport, leisure management & 4,6 & 8,5 & 5,6 \\
\hline Other & 0,6 & 8,6 & 4,4 \\
\hline
\end{tabular}

Obtained results show that at the present time considerable difference exists between the level of specialist's graduation and economic activity both in Russia in whole and particularly in the Rostov region. Herein in Russia correspondence between indicators under consideration only for several types of economic activity (construction, government, and agriculture) is typical. Economic activities such as construction, public administration, and education have a decisive influence on the structure of professional training in the Rostov region. Ratio of manufacturing in the structure of regional economy significantly influence on training specialist of SVE and produce less influence on graduation number from higher education institutions. The biggest mismatch was revealed in the domains of trade, agriculture, information and communication, science, and culture.

\section{Discussion}

The carried out analysis showed that on the meso-level of a regional economy significant difference between the structure of economic activity and therefore the composition of a regional's key competences and the structure of specialists' training in the system of vocational training is observed. The professional competencies of graduates formed within the framework of the reproduction of the educational potential of regions mostly remain unclaimed, since they are not focused on the real and promising needs of the economy. In the $90 \mathrm{~s}$ of the $20^{\text {th }}$ century the economy experienced structural transformations and deindustrialization, nowadays in its development it combines active growth in the service 
sector, including trade, and sluggish and geographically point processes of reindustrialization i.e. the revival of certain areas of material production on an innovative basis.

In this regard the assessment of the educational potential of a territory should be based not only on indicators characterizing the development of the territory, such as population density, the number of enterprises and organizations, industry structure, but also should take into account the factors of the formation of an innovative and digital economy. In particular the evaluation system should include indicators of innovative activity of economic entities - the degree of participation of organizations in the implementation of innovation activities, and according to types of economic activity as well. This very indicator projects the directions of development of the innovative economy and therefore it determines the needs for highly qualified personnel and determines the directions of development of the educational potential of territories.

The active development of digitalization determines the transition to qualitatively new productive forces, strengthens the role of information technologies and competencies in professional training of specialists and transforms the structure of professional qualities in human capital [13-14]. Digitalization is a consequence of the formation of a new sixth technological paradigm which being built on a new scientific and technological base it changes not only technology, but also the subject matter of the labor process itself and labor requirements [15]. This transition is accompanied by the depreciation of productive and human capital since the new stage requires qualitatively new productive forces including a new level of educational potential. Therefore, in our opinion, in the context of the formation of the digital economy, the development of the educational potential of regions of Russia should also be determined by the index of production that characterizes the change in the scale of production in the compared periods for certain economic activities. Analysis of the dynamics of changes in the sectoral structure of the economy under the influence of technological transformation will give possibility to predict the directions of key regional competencies formation as the basis of qualitatively new educational potential of territories corresponding to the modern technological paradigm of social and economic system of particular regions and the country in whole. Educational potential of territories formed as said above could become the basis for the effective development of regional innovative subsystems and the national innovation system of the whole country.

\section{References}

1. I. Bircan, F. Gencler, Procedia - Social and Behavioral Sciences, 195, 1348 - 1354 (2015) doi 10.1016/j.sbspro.2015.06.321

2. M. Kesti, Procedia Economics and Finance, 2, 257-264 (2012) doi: 10.1016/S22125671(12)00086-X

3. L. Gitelman, M. Kozhevnikov, Economy of the region, 14, 433-449 (2018) doi $10.17059 / 2018-2-8$

4. T. Tolstykh, Y. Vertakova, E. Shkarupeta, I. Shishkin, K. Krivyakin, Assessment of the Impact of Higher Education Development on the Social and Economic Processes in the Region. Proceedings of the 29th International Business Information Management Association Conference, 2180-2191 (Vienna Austria, May 3-4, 2017)

5. I. Korshunov, O. Gaponova, N. Gaponova, Economy of the region, 15(1), 107-120 (2019) doi 10.17059/2019-1-9

6. G. Siraya, Bulletin of the Astrakhan State Technical University. Series: Economics, 1, 108-116 (2020) doi.org/10.24143/2073-5537-2020-1-108-116 
7. M. Beisenova, G. Moldogaziyeva, I. Shevchenko, V. Sherstuk, A. Daribaeva, A. Demesinova, M. Seidakhmetov, Procedia - Social and Behavioral Sciences, 143, 599603 (2014) doi.org/10.1016/j.sbspro.2014.07.444

8. A. Mitroshin, Y. Shitova, Y. Shitov, Methods for assessing the quality of life of the population and socio-economic differentiation of territories (2018) doi 10.12737 / mono-graphy_5a129974a65cd9.88159942

9. Regions of Russia. Socio-economic indicators. Federal state statistics service, https://www.gks.ru/folder/210/document/13204 (Last accessed 12.07.2020)

10. Monitoring the development of the information society in the Russian Federation. Federal state statistics, http://www.gks.ru/free doc/new site/figure/anketa1-4.html/ (Last accessed 12.07.2020)

11. Information about the organization carrying out educational activities in educational programs of higher education - bachelor's programs, specialist programs, master's programs, https://minobrnauki.gov.ru/ru/activity/stat/highed/index.php (Last accessed 12.07.2020)

12. Indicators of Education in the Russian Federation, https://www.hse.ru/en/primarydata/io (Last accessed 22.07.2020)

13. O. Birzhak, E. Klochko, A. Adamenko, Lecture Notes in Networks and Systems, 111, 619-71626 (2020) doi 10.1007/978-3-030-39797-5_59

14. S. Glazyev, A. Aivazov, V. Belikov, Economy of the region, 14, 1-12, (2018) doi 10.17059/2018-1-1

15. Y. Odegov, V. Pavlova, Living standards of the population of Russian regions, 4(206), 19-25 (2017) doi: 10.12737/article_5a3c328a04f761.55103398 